\title{
AuPd Bimetallic Nanocrystals Embedded in Magnetic Halloysite Nanotubes: Facile Synthesis and Catalytic Reduction of Nitroaromatic Compounds
}

\author{
Lei Jia ${ }^{1,2}$, Tao Zhou ${ }^{1}$, Jun Xu ${ }^{1,2, *}$, Fenghai $\mathrm{Li}^{3}{ }^{3}$, Zhouqing $\mathrm{Xu}{ }^{1}$, Beibei Zhang ${ }^{1}$, Shengli Guo ${ }^{1}$, \\ Xiaoke Shen ${ }^{1}$ and Wensheng Zhang ${ }^{1}$ \\ 1 School of Chemistry and Chemical Engineering, Henan Polytechnic University, Jiaozuo 454000, China; \\ jlxj@hpu.edu.cn (L.J.); zhoutaohpu@163.com (T.Z.); zhouqx@hpu.edu.cn (Z.X.); zbbhpu@163.com (B.Z.); \\ guoshenglihpu@163.com (S.G.); shenxiaokehpu@163.com (X.S.); zhangwenshenghpu@163.com (W.Z.) \\ 2 Collaborative Innovation Center of Coal Work Safety, Jiaozuo 454000, China \\ 3 School of Chemistry and Engineering, Heze University, Heze 274015, China; hzlfh@163.com \\ * Correspondence: xjjl@hpu.edu.cn; Tel.: +86-391-398-7816
}

Received: 28 September 2017; Accepted: 13 October 2017; Published: 17 October 2017

\begin{abstract}
In this research, a facile and effective approach was developed for the preparation of well-designed AuPd alloyed catalysts supported on magnetic halloysite nanotubes (HNTs@ $\left.\mathrm{Fe}_{3} \mathrm{O}_{4} @ \mathrm{AuPd}\right)$. The microstructure and the magnetic properties of $\mathrm{HNTs} @ \mathrm{Fe}_{3} \mathrm{O}_{4} @ \mathrm{AuPd}$ were confirmed by transmission electron microscopy (TEM), high resolution TEM (HRTEM), energy-dispersive X-ray spectroscopy (EDS), and vibrating sample magnetometry (VSM) analyses. The catalysts, fabricated by a cheap, environmentally friendly, and simple surfactant-free formation process, exhibited high activities during the reduction of 4-nitrophenol and various other nitroaromatic compounds. Moreover, the catalytic activities of the $\mathrm{HNTs} @ \mathrm{Fe}_{3} \mathrm{O}_{4} @ \mathrm{AuPd}$ nanocatalysts were tunable via adjusting the atomic ratio of AuPd during the synthesis. As compared with the monometallic nanocatalysts $\left(\mathrm{HNTs} @ \mathrm{Fe}_{3} \mathrm{O}_{4} @ \mathrm{Au}\right.$ and $\mathrm{HNTs} @ \mathrm{Fe}_{3} \mathrm{O}_{4} @ \mathrm{Pd}$ ), the bimetallic alloyed $\mathrm{HNTs} @ \mathrm{Fe}_{3} \mathrm{O}_{4} @ \mathrm{AuPd}$ nanocatalysts exhibited excellent catalytic activities toward the reduction of 4-nitrophenol (4-NP) to 4-aminophenol. Furthermore, the as-obtained HNTs@ $\mathrm{Fe}_{3} \mathrm{O}_{4} @ \mathrm{AuPd}$ can be recycled several times, while retaining its functionality due to the stability and magnetic separation property.
\end{abstract}

Keywords: halloysite nanotubes; bimetallic; 4-nitrophenol; magnetic; AuPd alloy

\section{Introduction}

Noble metal nanoparticles (NPs), owing to their remarkable chemical and physical properties, have attracted significant attention in recent decades due to their potential use in electronics [1], optical devices [2], fuel cells [3], chemical sensors [4], catalysis [5-7] and biological materials [8-10]. Among these metals, gold nanoparticles (Au NPs) are frequently used for various catalytic reactions because $\mathrm{Au}$ catalyst is completely stable and active under mild condition [11,12]. For instance, Suvith et al. reported that Au NPs can be utilized for the catalytic degradation of methylene blue [13]. Toru Murayama et al. reported that nanoparticulate gold catalysts supported on niobium oxides $\left(\mathrm{Nb}_{2} \mathrm{O}_{5}\right)$ are effective catalysts for $\mathrm{CO}$ oxidation [14]. Furthermore, bimetallic NPs have gained much attention due to the bi-functional properties generated from the monometallic component, with applications in optics [15], fuel cells [3], and catalysis [16-18]. Many studies demonstrated that the addition of palladium to gold or silver leads to more effective and high catalytic performance in reactions as compared to monometallic NPs. For example, an AuPd-MnO $/ \mathrm{ZIF}-8-\mathrm{rGO}$ nanocatalyst prepared by a facile wet-chemical strategy showed highly efficient catalytic activity in 
the additive free dehydrogenation of formic acid [19]. In addition, Liu and co-workers reported that PdAg-N-doped-MOF-C can be used in catalytic transfer hydrogenation of nitro-compounds through the dramatically enhanced effect of Pd and Ag NPs in the reaction [20]. However, due to the high surface energy, free noble metal NPs aggregate easily, leading to a major reduction in catalytic activity and reusability. To solve this problem, many supporting materials, such as organic polymers materials [21], metal-organic framework [19], mesoporous silica [22], carbon materials [23], and so on [24,25], have been used to support and stabilize noble metal NPs.

Besides the above support materials, clay minerals are one of the more interesting nanostructured supports and are also regarded as a potential candidate for supports due to their excellent chemical and thermal stability. Among them, halloysite clay (HNT) is a natural and abundantly available nanoparticle formed by rolled kaolin sheets [26]. Very pure halloysite that possesses $90-98 \%$ of tubular structure (HNTs) is available in abundance only in France, Turkey, China, New Zealand, and USA [26,27]. Halloysite nanotubes (HNTs) are promising as a supporting material due to the inherent hollow tubular structure and charge differential between its inside and outside surfaces [28]. Due to its economical efficiency and biocompatibility [29-32], HNTs were recently studied for the development of innovative nanomaterials useful for catalytic [33,34] and biotechnological applications [35-38], with excellent geometrical and surface properties (large specific area, hollow tubular shape and tunable surface chemistry). In addition, when compared to other tubulose nanomaterials (such as boron nitride, metal oxide, and carbon nanotubes), HNTs are eco-compatible and non-toxic natural nanomaterials with remarkable and convenient applications in material science $[26,27]$. It is easy to imagine that in the near future HNTs could replace the much more expensive carbon nanotubes and in many cases, HNTs could be used in high technological applications where carbon nanotubes are just not suitable [26].

Moreover, researchers usually selected the reduction of 4-NP by sodium borohydride $\left(\mathrm{NaBH}_{4}\right)$ as a model reaction to test the catalytic activity of various nanocatalysts [39,40]. The most likely reason is that 4-NP is one of the most hazardous contaminants, which is present in waste-waters due to the usage of pharmaceuticals, pesticides and dyes [41]. 4-NP can irreversibly damage the central nervous system, liver, and kidney of animals and humans. Therefore, the removal of 4-NP is important to protect the human being. Accordingly, several methods, such as photocatalytic degradation [42], microbial degradation [43], hazardous substances adsorption [44], and electrochemical degradation [45] have been developed to remove 4-NP. However, among the above techniques, the reduction of 4-NP to 4-aminophenol (4-AP) is the easiest way to remove 4-NP from the environment. The product 4-AP is a useful intermediate for applications of antipyretic and analgesic drugs [46]. So, due to the reasons of energy saving and safe operation, it is necessary to develop an effective, stable, easily available, and highly efficient catalyst for the reduction of 4-NP to 4-AP in aqueous solution under mild environments. Usually, noble metal formed nanocatalysts are difficult to recycle and reuse from reaction solution because of their small sizes and the looking for suitable catalyst carrier is very essential. $\mathrm{HNTs} @ \mathrm{Fe}_{3} \mathrm{O}_{4}$ is an ideal magnetic support [33], which is convenient to prepare and has more active sites for the anchoring of noble metal NPs. It can not only prevent the aggregation of noble metal NPs, but can also facilitate the recycle of nanocatalysts with the help of a magnetic field.

In this work, we reported a facile and convenient method to prepare the magnetic recoverable nanocatalysts $\mathrm{HNTs} @ \mathrm{Fe}_{3} \mathrm{O}_{4} @ \mathrm{AuPd}$. Firstly, the HNTs were coated by magnetite $\mathrm{Fe}_{3} \mathrm{O}_{4}$ particles through a one-pot solvothermal synthesis method. Secondly, the magnetic $\mathrm{HNTs} @ \mathrm{Fe}_{3} \mathrm{O}_{4}$ were further modified by the AuPd alloyed NPs or monometallic Au or Pd NPs. The catalytic activities of the above nanocatalysts toward the reduction reaction of 4-NP and its derivative in the presence of $\mathrm{NaBH}_{4}$ were investigated. The synergistic effect between Pd and Au endowed $\mathrm{HNTs} @ \mathrm{Fe}_{3} \mathrm{O}_{4} @ \mathrm{AuPd}$ with superior activity when compared with monometallic HNTs@ $\mathrm{Fe}_{3} \mathrm{O}_{4} @ \mathrm{Pd}$ or $\mathrm{HNTs} @ \mathrm{Fe}_{3} \mathrm{O}_{4} @ \mathrm{Au}$ catalysts. 


\section{Results and Discussion}

\subsection{Structural and Morphology Characterization}

To investigate the formation of $\mathrm{HNT}_{0} \mathrm{Fe}_{3} \mathrm{O}_{4} @ \mathrm{AuPd}$ nanocomposited catalysts, X-ray diffraction (XRD) analyses were conducted. Figure 1 represents the XRD patterns of HNT coated by $\mathrm{Fe}_{3} \mathrm{O}_{4}, \mathrm{Au}-\mathrm{Pd}$ alloyed NPs, monometallic Au or Pd NPs, respectively. The exhibited characteristic diffraction peaks at $2 \theta=12^{\circ}, 20.3^{\circ}, 24.9^{\circ}$ originated from the HNTs for each sample, which demonstrate that the original inner structure of halloysite is not damaged during the whole preparation of $\mathrm{HNT} @ \mathrm{Fe}_{3} \mathrm{O}_{4} @ \mathrm{AuPd}$ nanocatalysts. The observed XRD peaks at $2 \theta=30.1^{\circ}, 35.5^{\circ}, 43.1^{\circ}, 53.5^{\circ}, 57.1^{\circ}$ can be indexed to the planes of fcc $\mathrm{Fe}_{3} \mathrm{O}_{4}$ (JCPDS-19-0629) [47]. The monometallic HNT@ $\mathrm{Fe}_{3} \mathrm{O}_{4} @ \mathrm{Au}$ and HNT@Fe $\mathrm{O}_{4} @ \mathrm{Pd}$ composited nanoparticles exhibit wide diffraction peaks which well match to fcc structure of bulk Au (JCPDS-65-8601) [48] and bulk Pd (JCPDS-65-2867) [49]. The weak diffractions detected for Au and Pd from XRD patterns of the above bimetallic and monometallic nancatalysts indicate the formation of small NPs [50]. Furthermore, as compared to the (111) diffraction peak of Pd NPs in $\mathrm{HNT}_{0} \mathrm{Fe}_{3} \mathrm{O}_{4} @ \mathrm{Pd}$, the diffraction peaks of $\mathrm{HNT} @ \mathrm{Fe}_{3} \mathrm{O}_{4} @ \mathrm{AuPd}$ shift to lower $2 \theta$ values towards the $\mathrm{Au}(111)$ peak, which is due to the increase of the lattice parameters and the formation of the crystalline Au-Pd alloy nanoparticles on $\mathrm{HNT} @ \mathrm{Fe}_{3} \mathrm{O}_{4}$ nanorods [19,51].

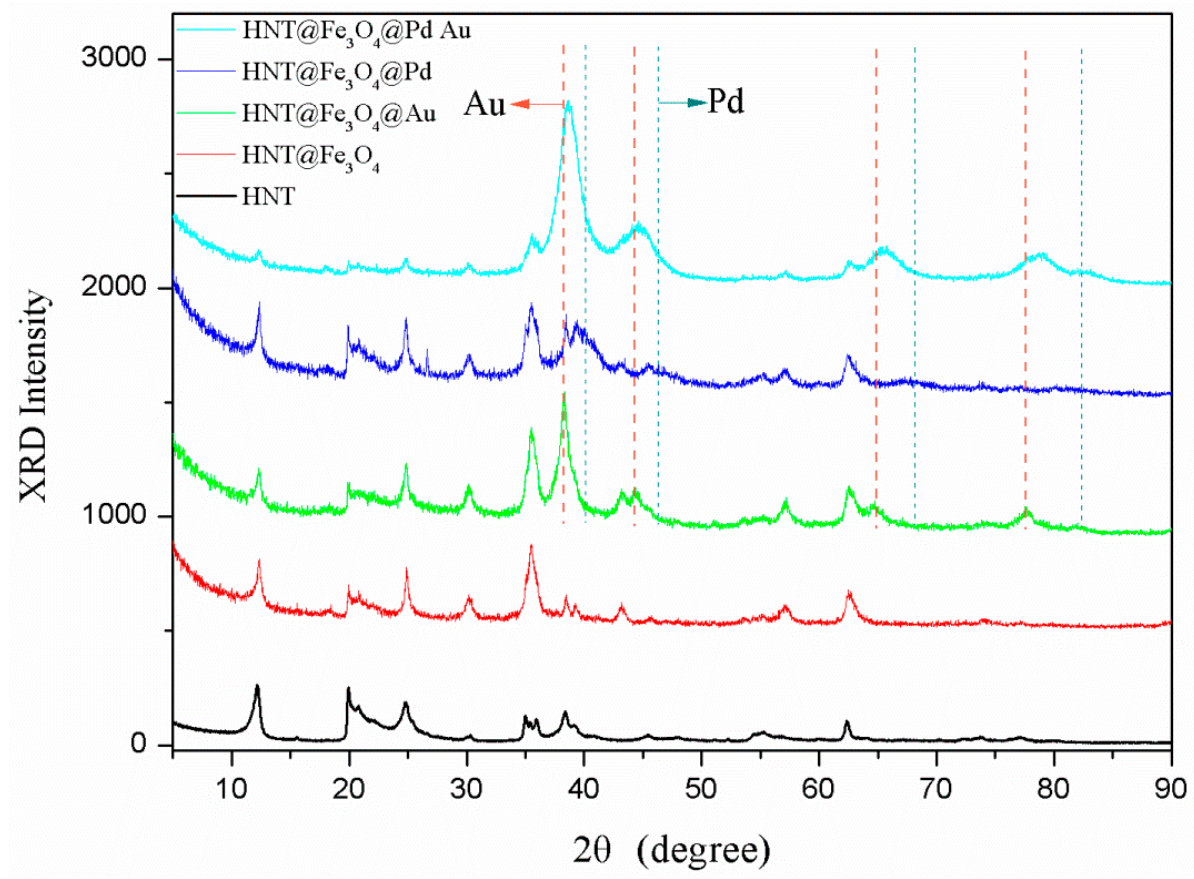

Figure 1. X-ray diffraction (XRD) patterns of as-synthesized nanocatalysts.

The TEM images of HNTs@ $\mathrm{Fe}_{3} \mathrm{O}_{4}$ and HNTs@ $\mathrm{Fe}_{3} \mathrm{O}_{4} @ \mathrm{AuPd}$ are shown in Figure 2. These images confirm that the nanocatalysts have been successfully fabricated and the HNTs still maintain their rod-like morphology during the preparation process. From Figure 2a, we can see the $\mathrm{Fe}_{3} \mathrm{O}_{4}$ nanoparticles (around $150 \mathrm{~nm}$ ) are attached on the HNTs surface without obvious aggregation. AuPd bimetallic nanoparticles (diameter below $5 \mathrm{~nm}$ ) have been successfully formed on the surface of $\mathrm{HNTs} @ \mathrm{Fe}_{3} \mathrm{O}_{4}$ by simply mixing the $\mathrm{HAuCl}_{4}$ and $\mathrm{K}_{2} \mathrm{PdCl}_{4}$ at room temperature. As shown in Figure $2 \mathrm{~b}, \mathrm{c}$, there are many small nanoparticles adhered to the HNTs or $\mathrm{Fe}_{3} \mathrm{O}_{4}$ surface after the coreduction and there are no isolated AuPd catalysts outside the $\mathrm{HNTs} @ \mathrm{Fe}_{3} \mathrm{O}_{4}$. High-resolution TEM (HRTEM) (Figure 2d) and size distribution images indicate that the average size of AuPd bimetallic is $3.61 \pm 0.28 \mathrm{~nm}$. The chemical composition and elemental distribution of $\mathrm{HNTs} @ \mathrm{Fe}_{3} \mathrm{O}_{4} @ \mathrm{AuPd}$ were investigated by EDS-mapping and the energy-dispersive X-ray spectroscopy (EDX). HAADF-STEM 
measurements (Figure 3) were carried out to investigate the elemental spatial distribution of Pd and Au. Here, it is necessary to mention that for the ultrafine AuPdNPs, while it is really difficult to get their HAADF-STEM results. Therefore, AuPd NPs with some aggregation were found by the HAADF-STEM test. The dark-field images indicate a abundant deposition of AuPd nanocatalysts on the magnetic support. Clearly, from Figure 3, $\mathrm{Si}, \mathrm{Al}$ and Fe atoms are distributed on $\mathrm{HNTs}_{\mathrm{s}} @ \mathrm{Fe}_{3} \mathrm{O}_{4}$, whilst $\mathrm{Pd}$ and $\mathrm{Au}$ atoms are distributed uniformly over the entire $\mathrm{HNTs} @ \mathrm{Fe}_{3} \mathrm{O}_{4} @ \mathrm{AuPd}$ nanocatalysts, which provide a strong proof on the formation of alloy decorated nanocatalyst [51]. Furthermore, the typical HRTEM image (Figure 2d) of the AuPd NPs indicated that the interplanar spacing of the particle lattice is $0.229 \mathrm{~nm}$, which approximated both the (111) lattice spacing of face centered cubic (fcc) $\mathrm{Pd}(0.223 \mathrm{~nm})$ and $\mathrm{Au}(0.234 \mathrm{~nm})$, and this may indicate that line defects are formed [52]. From the EDX image (Figure 4a), we can observe the existence of $\mathrm{Si}, \mathrm{Al}, \mathrm{Fe}$, Au and Pd elements, which can also prove the successful deposition of $\mathrm{Au}$ and $\mathrm{Pd}$ on the $\mathrm{HNTs} @ \mathrm{Fe}_{3} \mathrm{O}_{4}$ catalysts carrier. According to the ICP-AES analyses, the content of the total metal supported on the $\mathrm{HNTs} @ \mathrm{Fe}_{3} \mathrm{O}_{4} @ \mathrm{AuPd}$ nanocatalysts is $2.81 \mathrm{wt}$ \% and the atomic ratio of $\mathrm{Au}: \mathrm{Pd}$ is 0.402:0.598, which is consistent with the designed ratio. As shown in Figure $4 b$, the magnetic properties of $\mathrm{HNTs}_{\mathrm{N}} @ \mathrm{Fe}_{3} \mathrm{O}_{4}$ and HNTs@Fe $\mathrm{O}_{4} @ \mathrm{AuPd}$ at room temperature demonstrate that the decreasing magnetization values can be assigned to the loading of non-magnetic AuPd nanoparticles. However, the current magnetism is still strong enough for the recycling and reusing of the catalysts during the whole catalytic experiments.

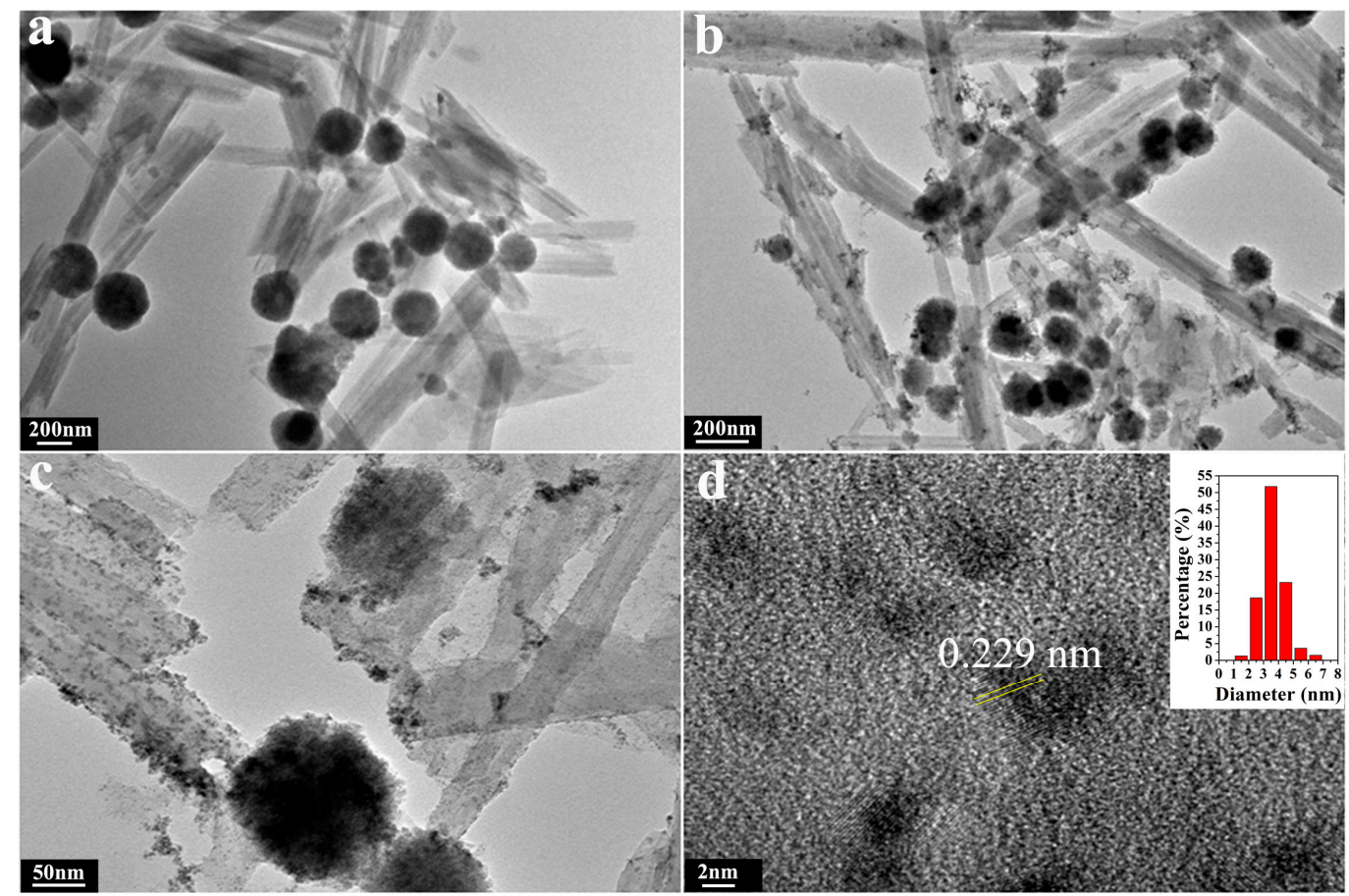

Figure 2. Transmission electron microscopy (TEM) images of $\mathrm{HNTs} @ \mathrm{Fe}_{3} \mathrm{O}_{4}(\mathbf{a}), \mathrm{HNTs} @ \mathrm{Fe}_{3} \mathrm{O}_{4} @ \mathrm{AuPd}$ $(\mathbf{b}, \mathbf{c})$; high resolution TEM (HRTEM) image of AuPd bimetallic nanoparticles on the HNTs@ $@ \mathrm{Fe}_{3} \mathrm{O}_{4}$ catalysts carrier (d); The inner image in (d) is the size distribution of AuPd bimetallic NPs. 

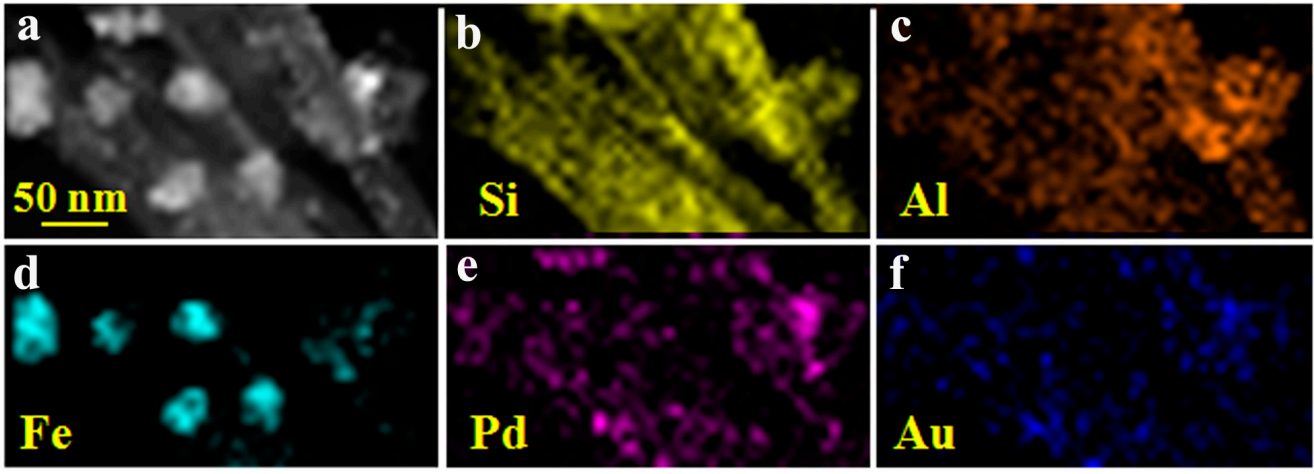

Figure 3. HAADF-STEM images of $\mathrm{HNTs} @ \mathrm{Fe}_{3} \mathrm{O}_{4} @ \mathrm{AuPd}(\mathbf{a})$; energy-dispersive X-ray spectroscopy (EDX) mapping of Si element (b); Al element (c); Fe element (d); Pd element (e); and, Au element (f).
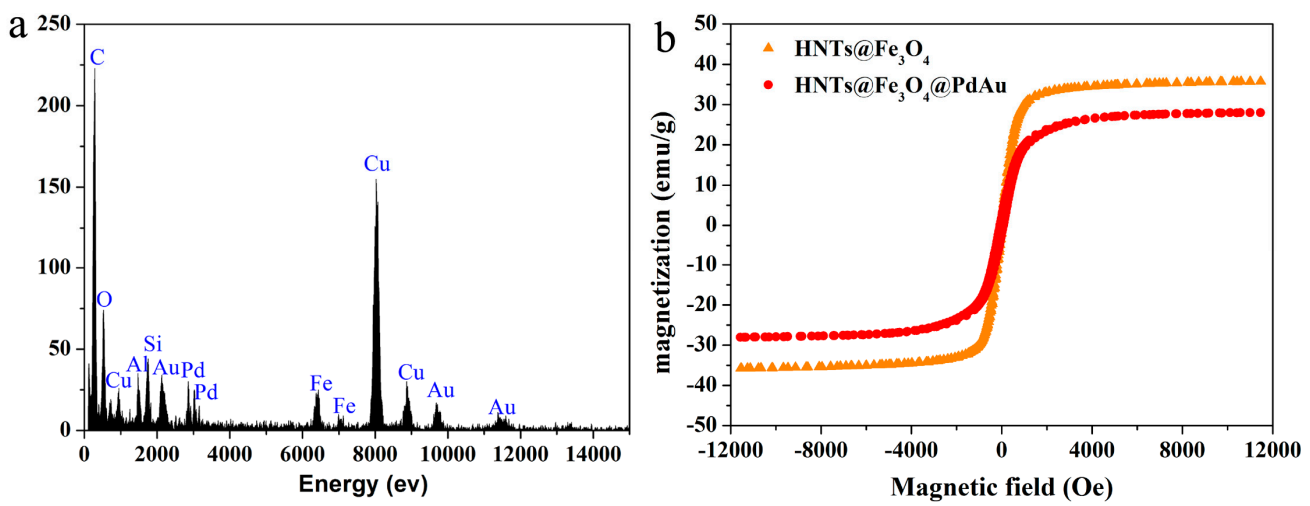

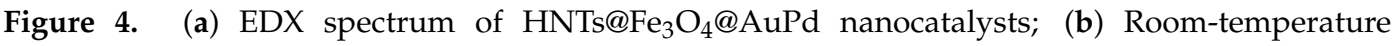
magnetization hysteresis loops of the as-prepared $\mathrm{HNTs} @ \mathrm{Fe}_{3} \mathrm{O}_{4}$ and $\mathrm{HNTs} @ \mathrm{Fe}_{3} \mathrm{O}_{4} @ \mathrm{AuPd}$.

\subsection{Catalytic Activities of Bimetallic or Monometallic Au/Pd Modified Nanocatalysts in the Reduction of 4-NP}

The catalytic activities of as-prepared bimetallic and monometallic nanocatalysts were tested by the catalysts for the reduction of 4-NP with an excess of $\mathrm{NaBH}_{4}$, as depicted in Figure 5. The conversion from 4-NP to 4-AP can be easily monitored by the UV-vis spectroscopy. Generally, the UV-Visible spectra of 4-NP solutions have a distinct spectral profile with a maximum absorption peak at $317 \mathrm{~nm}$ in neutral or acidic situation, which is presented in Figure 5a. After addition of $\mathrm{NaBH}_{4}$, the absorption band shifts to $400 \mathrm{~nm}$ immediately, accompanied with the color change from light yellow to bright yellow. This peak shift is due to the formation of 4-nitrophenolate ion as the alkalinity of the solution increased [39]. Without the addition of the catalysts, the maximum absorption peak at $400 \mathrm{~nm}$ can not be altered, indicating that there is no reduction reaction, which is caused by the high kinetic barrier between 4-nitrophenolate ion and $\mathrm{BH}_{4}{ }^{-}$ion.

After the addition of a small amount of $\mathrm{HNT} @ \mathrm{Fe}_{3} \mathrm{O}_{4} @ \mathrm{Au}_{40} \mathrm{Pd}_{60}$ into the 4-NP and $\mathrm{NaBH}_{4}$ mixed solution, the color of the solution changed from bright yellow to colorless quickly, signalling the completion of the reaction. Time-dependent absorbance spectra of this reaction shows the intensity of the absorption spectra at $400 \mathrm{~nm}$ gradually decrease along with a concomitant increase of the $300 \mathrm{~nm}$ peak of 4-aminophenol, revealing the formation of 4-AP [51]. After $8 \mathrm{~min}$, the peak at $400 \mathrm{~nm}$ is no longer observed, indicating that the reduction reaction is completed (Figure $5 \mathrm{~b}$ ). We proposed that $\mathrm{BH}_{4}{ }^{-}$would adsorb onto the surface of $\mathrm{HNT} @ \mathrm{Fe}_{3} \mathrm{O}_{4} @ \mathrm{Au}_{40} \mathrm{Pd}_{60}$ and divert activated hydrogen to the AuPd active centre to form a metal hydride complex [53]. Meanwhile, 4-NP can also simultaneously stick to the surfaces of $\mathrm{HNT} @ \mathrm{Fe}_{3} \mathrm{O}_{4} @ \mathrm{Au}_{40} \mathrm{Pd}_{60}$ via chemical adsorption [54]. In the above factors, the transformation of adsorbed hydrogen species to 4-NP can reduce the nitro groups to amino groups, which is strongly supported by previous results $[55,56]$. 
For a comprehensive elucidation of the catalytic property of the $\mathrm{HNT} @ \mathrm{Fe}_{3} \mathrm{O}_{4} @ \mathrm{Au}_{40} \mathrm{Pd}_{60}$ and the synergetic effects of $\mathrm{Au}$ and $\mathrm{Pd}$ catalytic architecture in the reduction of 4-NP, we investigated the catalytic behaviour of monometallic $\mathrm{HNT} @ \mathrm{Fe}_{3} \mathrm{O}_{4} @ \mathrm{Au}, \mathrm{HNT} @ \mathrm{Fe}_{3} \mathrm{O}_{4} @ \mathrm{Pd}$, and bimetallic $\mathrm{HNT} @ \mathrm{Fe}_{3} \mathrm{O}_{4} @ \mathrm{Au}_{40} \mathrm{Pd}_{60}$ with different molar compositions of $\mathrm{Au}$ versus Pd under the identical conditions (the amount of each catalyst is controlled at $5 \mu \mathrm{g}$ ). As shown in the time-dependent UV-vis absorption spectra of Figure 5c,d, the time for $\mathrm{HNT}_{\mathrm{N}} \mathrm{Fe}_{3} \mathrm{O}_{4} @ \mathrm{Pd}$ to finish the reduction is slight shorter than that for $\mathrm{HNT} @ \mathrm{Fe}_{3} \mathrm{O}_{4} @ \mathrm{Au}$, while the time of the two catalysts used are obvious longer than that for $\mathrm{HNT} @ \mathrm{Fe}_{3} \mathrm{O}_{4} @ \mathrm{Au}_{40} \mathrm{Pd}_{60}$. These results indicate that the catalytic activity of magnetic HNT-based AuPd alloyed bimetallic nanocatalysts is evidently enhanced as compared to the Au or $\mathrm{Pd}$ monometallic nanocatalysts. As a matter of fact, the catalytic activities of the $\mathrm{HNT} @ \mathrm{Fe}_{3} \mathrm{O}_{4} @ \mathrm{AuPd}$ nanocomposite are tunable by altering the $\mathrm{Au}$ versus $\mathrm{Pd}$ atomic ratios. The catalytic reactions own the highest reaction rate when the atomic ratio of the alloyed catalysts reaches $\mathrm{Au}_{40} \mathrm{Pd}_{60}$, which can be understood in Figure 6a.
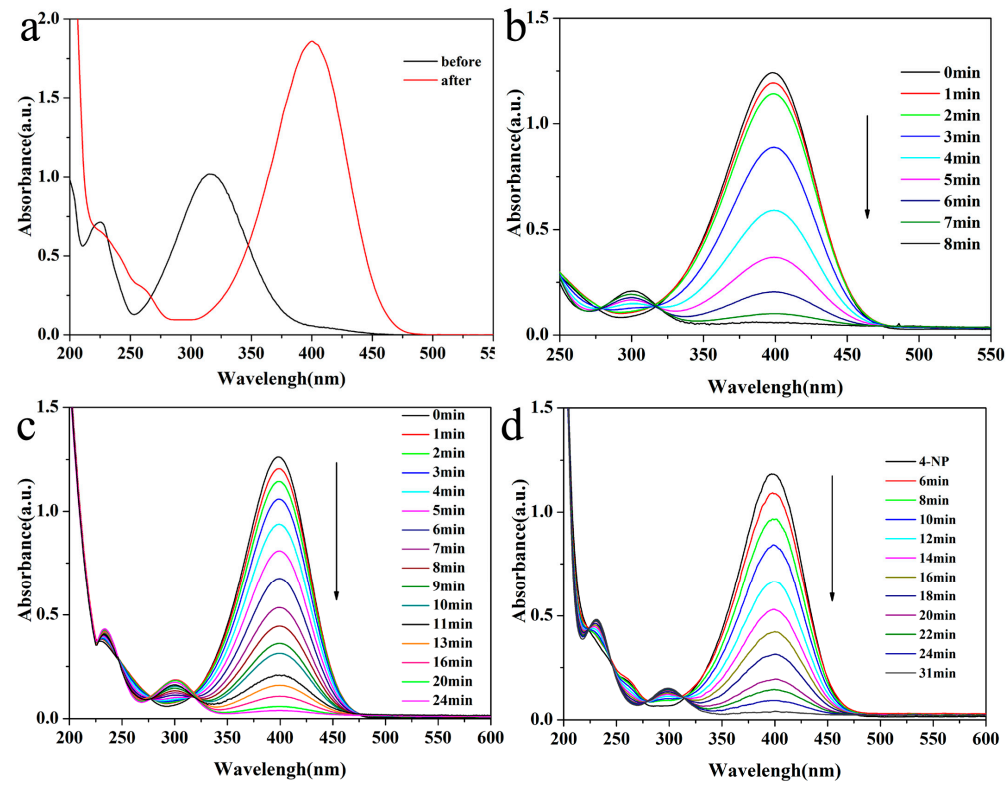

Figure 5. (a) UV-vis spectra of 4-NP before and after adding $\mathrm{NaBH}_{4}$ solution without catalysts; time-dependent UV-vis absorption spectra of reduction of 4-NP by $\mathrm{NaBH}_{4}$ in presence of $\mathrm{HNT} @ \mathrm{Fe}_{3} \mathrm{O}_{4} @ \mathrm{Au}_{40} \mathrm{Pd}_{60}(\mathbf{b}) ; \mathrm{HNT} @ \mathrm{Fe}_{3} \mathrm{O}_{4} @ \mathrm{Pd}(\mathbf{c})$ and $\mathrm{HNT} @ \mathrm{Fe}_{3} \mathrm{O}_{4} @ \mathrm{Au}(\mathbf{d})$.

To further evaluate the catalytic activities of the above different nanocatalysts, a pseudo-first order kinetics equation was applied, which is due to the amount of $\mathrm{BH}_{4}{ }^{-}$in the catalytic system is more excessive than that of 4-NP and the reaction rate is not affected by the concentration of $\mathrm{BH}_{4}{ }^{-}$. The experiment was carried out under the same conditions and the rate constant $(\mathrm{k})$ is calculated as: $k_{a p} t=\ln \left(C_{t} / C_{0}\right)$, where $C_{0}$ is the initial absorbance of the reagents at the maximum absorption wavelength, $C_{t}$ is the absorbance of reagents at maximum absorption wavelength under different time $\mathrm{t}$ and $\mathrm{K}_{\mathrm{ap}}$ is the apparent rate constant. Figure 6a shows the approximately linear relationships of $\ln \left(A_{t} / A_{0}\right)$ vs. reaction time in the reaction catalyzed by the as synthesized nanocatalysts. It can be clearly seen that the reactions follow the pseudo-first-order reaction kinetics. Hence, the apparent rate constants obtained from the slopes of the linearly plots are $0.520,0.389,0.216,0.023$, and $0.174 \mathrm{~min}^{-1}$ for the HNT@Fe $\mathrm{O}_{4} @ \mathrm{Au}_{40} \mathrm{Pd}_{60}, \mathrm{HNT} @ \mathrm{Fe}_{3} \mathrm{O}_{4} @ \mathrm{Au}_{67} \mathrm{Pd}_{33}, \mathrm{HNT} @ \mathrm{Fe}_{3} \mathrm{O}_{4} @ \mathrm{Au}_{50} \mathrm{Pd}_{50}, \mathrm{HNT} @ \mathrm{Fe}_{3} \mathrm{O}_{4} @ \mathrm{Au}$ and $\mathrm{HNT} @ \mathrm{Fe}_{3} \mathrm{O}_{4} @ \mathrm{Pd}$, respectively. It is obvious that all the $\mathrm{HNT} @ \mathrm{Fe}_{3} \mathrm{O}_{4} @ \mathrm{Au}_{40} \mathrm{Pd}_{60}$ nanocatalysts have the highest catalytic ability and its reaction rate is about 22.61 and 2.98 times faster than that of the monometallic Au or Pd modified nanocatalysts, which is accordance with the results obtained from the time-dependent UV-vis absorption spectra. 
Furthermore, the scope of the catalytic activity of $\mathrm{HNT} @ \mathrm{Fe}_{3} \mathrm{O}_{4} @ \mathrm{Au}_{40} \mathrm{Pd}_{60}$ in the reduction for other nitroaniline derivates was also investigated. All the catalytic conditions of these analogues are same as that of 4-NP and the reaction progress of the nitroaniline was monitored by UV-vis absorption spectrometry. The data of reaction time and the conversion were calculated and are listed in Table 1, revealing our catalysts have excellent catalytic activities with perfect yield toward nitrophenol and nitroaniline derivatives regardless of the types and position of the substituents. Four kinds of nitroaniline can be reduced within 8 min with a conversion more than 99\%. Interestingly, when the HNT@ $\mathrm{Fe}_{3} \mathrm{O}_{4} @ \mathrm{Au}_{40} \mathrm{Pd}_{60}$ was used to reduce the nitrotoluene analog substrate, it displayed a lower activity than those of nitroaniline and nitrophenol, which indicated that the reaction processes of nitrotoluene derivatives are more complicated than those of nitroaniline and nitrophenol derivatives [57].
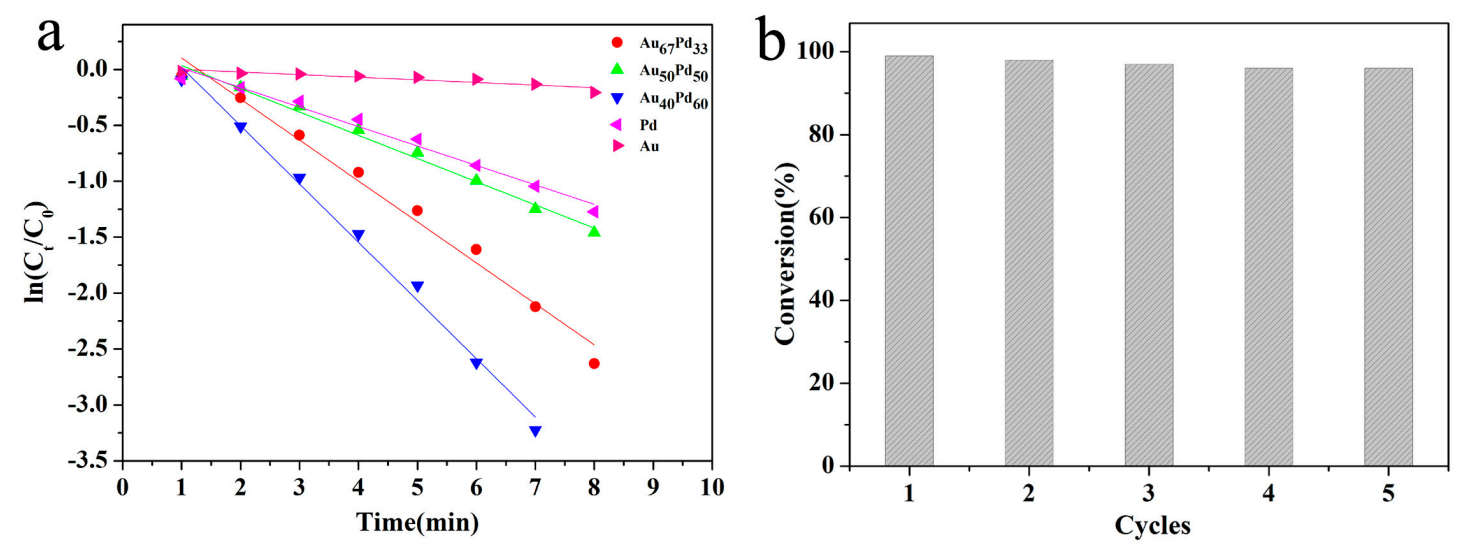

Figure 6. (a) The relationships between $\ln \left(\mathrm{C}_{t} / \mathrm{C}_{0}\right)$ and reaction time $t(d)$ for the reduction of 4-NP over different catalysts; (b) the reusability of the $\mathrm{Au}_{40} \mathrm{Pd}_{60} @ \mathrm{HNT} @ \mathrm{Fe}_{3} \mathrm{O}_{4}$ nanocatalysts for the catalytic reduction of 4-NP.

Table 1. Reduction of various nitrobenzenes using $\mathrm{HNT} @ \mathrm{Fe}_{3} \mathrm{O}_{4} @ \mathrm{Au}_{40} \mathrm{Pd}_{60}$ catalysts.

\begin{tabular}{cccc}
\hline Entry & Compound & Time/min & Conversion/\% \\
\hline $\mathbf{1}$ & p-Nitroaniline & 8 & 99 \\
$\mathbf{2}$ & m-Nitroaniline & 6 & 99 \\
$\mathbf{3}$ & o-Nitroaniline & 5 & 99 \\
$\mathbf{4}$ & 2,4-Nitroaniline & 7 & 99 \\
$\mathbf{5}$ & m-Nitrotoluene & 68 & 81 \\
$\mathbf{6}$ & o-Nitrotoluene & 76 & 75 \\
$\mathbf{7}$ & 2,4-Dinitrotoluene & 82 & 79 \\
\hline
\end{tabular}

\subsection{Reusability of the HNT@Fe $\mathrm{O}_{4} @ \mathrm{Au}_{40} P d_{60}$}

It is well known that the reusability is a main advantage of using a heterogeneous catalyst rather than a homogeneous catalyst. As the $\mathrm{Fe}_{3} \mathrm{O}_{4}$ NPs have remarkable magnetic properties [58], the catalysts were recovered by simple magnetic separation with the help of a magnetic field after completion of the reduction reaction and then washed with water for reusing in the next cycle. The reusability of the HNT@Fe $\mathrm{O}_{4} @ \mathrm{Au}_{40} \mathrm{Pd}_{60}$ were studied for the reduction of 4-nitrophenol with $\mathrm{NaBH}_{4}$. As shown in Figure 6b, even after five successive recycle, $\mathrm{HNT} @ \mathrm{Fe}_{3} \mathrm{O}_{4} @ \mathrm{Au}_{40} \mathrm{Pd}_{60}$ still displayed excellent conversion efficiency without significant loss of its activity. Besides the catalytic activity and reusability, the stability of the catalysts is also a very important issue for industrial applications. To examine the stability of the nanocatalysts, the reduction reaction was repeated using composited catalysts for more than three months. The conversion of 4-NP was similar after the catalysts are prepared three months 
later, suggesting that the catalysts were stable and can be used within three months without an obvious loss of activity [59].

\section{Materials and Methods}

\subsection{Materials}

Halloysite was purchased from China-Kaolinite Company (Suzhou, China). Ferric chloride hexahydrate $\left(\mathrm{FeCl}_{3} \cdot 6 \mathrm{H}_{2} \mathrm{O}\right)$, sodium acetate $(\mathrm{NaAc})$, polyethylene glycol (PEI), ethylene glycol (EG), potassium tetrachloropalladate $\left(\mathrm{K}_{2} \mathrm{PdCl}_{4}\right) \mathrm{m}$ and hydrogen tetrachloroaurate $\left(\mathrm{HAuCl}_{4}\right)$ were obtained from Sinopharm Chemistry Reagent Co., Ltd. (Beijing, China). 4-nitrophenol, p-nitroaniline, m-nitroaniline, o-Nitroaniline (o-NA), 2,4-Nitroaniline and sodium hydroxide $\left(\mathrm{NaBH}_{4}\right)$ were bought from Sigma Aldrich. All of the chemicals were of chemical reagent grade and used without any further purification. Ultrapure water was prepared by using NANO Pure Infinity System (Barnstead/Thermolyne Corp, Dubuque, IA, USA).

\subsection{Preparation of $\mathrm{HNT} @ \mathrm{Fe}_{3} \mathrm{O}_{4}$}

HNT coated by $\mathrm{Fe}_{3} \mathrm{O}_{4}$ were synthesized through a solvothermal reaction according to a previously described method with some modification [60]. Briefly, $1 \mathrm{~g}$ of $\mathrm{FeCl}_{3} \cdot 6 \mathrm{H}_{2} \mathrm{O}$ was added to $30 \mathrm{~mL}$ of ethylene glycol. A clear yellow solution was obtained after sonication for $3 \mathrm{~min}$. Then, $2.7 \mathrm{~g}$ of sodium acetate (NaAc) and $0.75 \mathrm{~g}$ PEI were added to the above solution and stirred for another $0.5 \mathrm{~h}$. Subsequently, $0.3 \mathrm{~g}$ HNT was added. When the mixed solution was ultrasonically dispersed for $3 \mathrm{~h}$ to form a homogeneous dispersion, the mixture solution was transferred to a Teflon-lined stainless-steel autoclave $\left(50 \mathrm{~mL}\right.$ capacity). The autoclave was sealed and maintained at $200{ }^{\circ} \mathrm{C}$. After reaction for $8 \mathrm{~h}$, the autoclave was naturally cooled to ambient temperature. The obtained $\mathrm{HNT} @ \mathrm{Fe}_{3} \mathrm{O}_{4}$ black magnetic particles were collected by an external magnetic field and washed four times with ethanol and deionized water in sequence. The product was then dried in vacuum at 60 for $12 \mathrm{~h}$.

\subsection{Preparation of HNTs@Fe $\mathrm{O}_{4} @ A u P d, H N \mathrm{H}_{s} @ \mathrm{Fe}_{3} \mathrm{O}_{4} @ A u$ and $\mathrm{HNTs}_{\mathrm{s}} @ \mathrm{Fe}_{3} \mathrm{O}_{4} @ P d$}

In a typical synthesis of $\mathrm{HNTs} @ \mathrm{Fe}_{3} \mathrm{O}_{4} @ \mathrm{AuPd}, 5.0 \mathrm{~mL}$ aqueous solution containing $\mathrm{HNT} @ \mathrm{Fe}_{3} \mathrm{O}_{4}$ $(50 \mathrm{mg}), \mathrm{HAuCl}_{4}(0.5 \mathrm{~mL}, 10 \mathrm{mM})$, and $\mathrm{K}_{2} \mathrm{PdCl}_{4}(0.5 \mathrm{~mL} 10 \mathrm{mM})$ was kept in a glass bottle under stirring for $3 \mathrm{~h}$. Then, the fresh $1.0 \mathrm{~mL}$ aqueous solution $\mathrm{NaBH}_{4}(28 \mathrm{mg}, 0.7 \mathrm{mmol})$ was added and the resulting solution was stirred for another $0.5 \mathrm{~h}$ at ambient temperature. Then, the reaction mixture was centrifuged and washed with pure water to remove the remaining reagents. For comparison, other catalysts were also prepared using the same method: (1) $\mathrm{HNT}_{\mathrm{FNe}} \mathrm{O}_{4}\left(50 \mathrm{mg}\right.$ ) and $\mathrm{HAuCl}_{4}$ (0.5 mL, 10 mM) for HNTs@ $\mathrm{Fe}_{3} \mathrm{O}_{4} @ \mathrm{Au},(2) \mathrm{HNT} @ \mathrm{Fe}_{3} \mathrm{O}_{4}(50 \mathrm{mg})$ and $\mathrm{K}_{2} \mathrm{PdCl}_{4}(0.75 \mathrm{~mL}, 10 \mathrm{mM})$ for HNTs@Fe $\mathrm{O}_{4} @ \mathrm{Pd}$ and (3) $\mathrm{HNT}_{\mathrm{Fe}_{3} \mathrm{O}_{4}(50 \mathrm{mg}), 0.5 \mathrm{~mL} 10 \mathrm{mM} \mathrm{HAuCl}}$ and v mL $10 \mathrm{mM} \mathrm{K}_{2} \mathrm{PdCl}_{4}$ ( v = 0.25, 0.75) for HNTs@ $\mathrm{Fe}_{3} \mathrm{O}_{4} @ \mathrm{Au}_{\mathrm{x}} \mathrm{Pd}_{\mathrm{y}}$.

\subsection{Catalytic Reduction of Nitrobenzene}

The reduction of 4-NP with $\mathrm{NaBH}_{4}$ was chosen to examine the catalytic activity and reusability of the HNTs@ $\mathrm{Fe}_{3} \mathrm{O}_{4} @ \mathrm{Au}_{40} \mathrm{Pd}_{60}$ catalysts. In a typical procedure, $1 \mathrm{~mL}$ of $4-\mathrm{NP}(0.1 \mathrm{mM})$ and $1.0 \mathrm{~mL}$ of fresh $\mathrm{NaBH}_{4}(10 \mathrm{mM})$ was taken in a quartz cuvette, followed by addition of $20 \mu \mathrm{L}$ of catalysts $(0.25 \mathrm{mg} / \mathrm{mL})$ to the mixture. The reaction solution was immediately monitored using UV-vis spectrophotometer at $1 \mathrm{~min}$ interval. The color of the solution changed gradually from yellow to colorless. The catalytic reduction of other nitroaniline were conducted under the same condition of 4-NP. Following the similar procedures, $\mathrm{HNT} @ \mathrm{Fe}_{3} \mathrm{O}_{4} @ \mathrm{Au}, \mathrm{HNT} @ \mathrm{Fe}_{3} \mathrm{O}_{4} @ \mathrm{Pd}_{\text {, }}$ and $\mathrm{HNT} @ \mathrm{Fe}_{3} \mathrm{O}_{4} @ \mathrm{Au}_{\mathrm{x}} \mathrm{Pd}_{\mathrm{y}}$ (each of $5 \mu \mathrm{g}$ ) were also used as catalysts for the reduction of 4-NP. 


\subsection{Characterization}

Transmission electron microscopy (TEM), high resolution transmission electron microscopy (HRTEM), and the energy dispersive spectra (EDS) were determined by a Tecnai-G2-F30 at acceleration voltages of $200 \mathrm{kV}$. X-ray diffraction (XRD) measurements were carried out on a X'pert PRO X-ray power diffractometer using $\mathrm{Cu}$ Ka radiation of $1.5406 \mathrm{~A}(40 \mathrm{kV}, 30 \mathrm{~mA})$. Magnetization measurements were performed on a vibrating sample magnetometry (VSM, LAKESHORE-7304, Westerville, OH, USA) at room temperature. The UV measurement was finished on a Shimadzu UV-240 spectrophotometer. $\mathrm{Au}, \mathrm{Pd}$ contents of the samples were determined by inductively coupled plasma-atomic emission spectroscopy (ICP-AES) using an IRIS Advantage ER/S spectrophotometer.

\section{Conclusions}

In conclusion, we fabricated magnetically separable and well dispersed bimetallic $\mathrm{Au}_{40} \mathrm{Pd}_{60}$

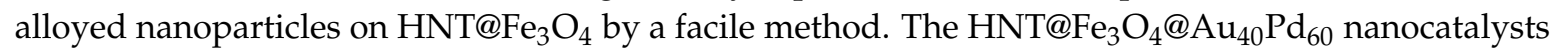
were explored for the reduction of organic pollutants in an aqueous medium. When compared with the monometallic HNT@ $@ \mathrm{Fe}_{3} \mathrm{O}_{4} @ \mathrm{Au}$ and $\mathrm{HNT} @ \mathrm{Fe}_{3} \mathrm{O}_{4} @ \mathrm{Pd}$ nanocatalysts prepared under the same conditions, the AuPd alloyed $\mathrm{HNT} @ \mathrm{Fe}_{3} \mathrm{O}_{4} @ \mathrm{Au}_{40} \mathrm{Pd}_{60}$ nanocatalysts exhibited the much better catalytic performance, which may be ascribed to the synergistic effects of $\mathrm{Pd}$ and $\mathrm{Au}$. Furthermore, the $\mathrm{HNT} @ \mathrm{Fe}_{3} \mathrm{O}_{4} @ \mathrm{Au}_{40} \mathrm{Pd}_{60}$ catalysts can be easily separated from the reaction system with the help of an external magnet and reused several cycles without significant loss of the activity. The as-obtained hybrids may become ideal recyclable catalysts for the reduction of aromatic nitro compounds owing to their stability and efficient magnetism.

Acknowledgments: This work was supported, in part, by the National Natural Science Foundation of China (No. 51773052, No. 21404033 and No. 21401046), the Science and Technology Research Project of Henan province (162102210065 and 152102210314) and the Fundamental Research Funds for the Universities of Henan Province.

Author Contributions: Lei Jia conceived and designed the experiments; Tao Zhou, Zhouqing Xu, Beibei Zhang, Fenghai Li, Shengli Guo and Xiaoke Shen performed the experiments and analyzed the data; Jun Xu provided the concept of this research and managed all the experimental and writing process as the corresponding authors; all authors discussed the results and commented on the manuscript.

Conflicts of Interest: The authors declare no conflict of interest.

\section{References}

1. Toyoda, K.; Hamada, I.; Lee, K.; Yanagisawa, S.; Morikawa, Y. Density functional theoretical study of pentacene/noble metal interfaces with van der Waals corrections: Vacuum level shifts and electronic structures. J. Chem. Phys. 2010, 132, 134703. [CrossRef] [PubMed]

2. Mulvihill, M.J.; Ling, X.Y.; Henzie, J.; Yang, P. Anisotropic etching of silver nanoparticles for plasmonic structures capable of single-particle SERS. J. Am. Chem. Soc. 2009, 132, 268-274. [CrossRef] [PubMed]

3. Bulut, A.; Yurderi, M.; Karatas, Y.; Say, Z.; Kivrak, H.; Kaya, M.; Gulcan, M.; Ozensoy, E.; Zahmakiran, M. $\mathrm{MnO}_{\mathrm{x}}$-Promoted PdAg Alloy Nanoparticles for the Additive-Free Dehydrogenation of Formic Acid at Room Temperature. ACS Catal. 2015, 5, 6099-6110. [CrossRef]

4. Doria, G.; Conde, J.; Veigas, B.; Giestas, L.; Almeida, C.; Assunção, M.; Rosa, J.; Baptista, P.V. Noble metal nanoparticles for biosensing applications. Sensors 2012, 12, 1657-1687. [CrossRef] [PubMed]

5. Hunt, S.T.; Milina, M.; Alba-Rubio, A.C.; Hendon, C.H.; Dumesic, J.A.; Román-Leshkov, Y. Self-assembly of noble metal monolayers on transition metal carbide nanoparticle catalysts. Science 2016, 352, 974-978. [CrossRef] [PubMed]

6. Sapurina, I.; Stejskal, J.; Šeděnková, I.; Trchová, M.; Kovářová, J.; Hromádková, J.; Kopecká, J.; Cieslar, M.; El-Nasr, A.A.; Ayad, M.M. Catalytic activity of polypyrrole nanotubes decorated with noble-metal nanoparticles and their conversion to carbonized analogues. Synth. Met. 2016, 214, 14-22. [CrossRef]

7. Zhang, L.; Fan, Q.; Sha, X.; Zhong, P.; Zhang, J.; Yin, Y.; Gao, C. Self-Assembly of Noble Metal Nanoparticles into Sub-100 nm Colloidosomes with Collective Optical and Catalytic Properties. Chem. Sci. 2017, 8, 6103-6110. [CrossRef] 
8. Howes, P.D.; Chandrawati, R.; Stevens, M.M. Colloidal nanoparticles as advanced biological sensors. Science 2014, 346, 1247390. [CrossRef] [PubMed]

9. Rai, M.; Ingle, A.P.; Birla, S.; Yadav, A.; Santos, C.A.D. Strategic role of selected noble metal nanoparticles in medicine. Crit. Rev. Microbiol. 2016, 42, 696-719. [CrossRef] [PubMed]

10. Rai, M.; Ingle, A.P.; Gupta, I.; Brandelli, A. Bioactivity of noble metal nanoparticles decorated with biopolymers and their application in drug delivery. Int. J. Pharm. 2015, 496, 159-172. [CrossRef] [PubMed]

11. Bi, Q.Y.; Du, X.L.; Liu, Y.M.; Cao, Y.; He, H.Y.; Fan, K.N. Efficient subnanometric gold-catalyzed hydrogen generation via formic acid decomposition under ambient conditions. J. Am. Chem. Soc. 2012, 134, 8926-8933. [CrossRef] [PubMed]

12. Miyamura, H.; Yasukawa, T.; Kobayashi, S. Aerobic oxidative esterification of alcohols catalyzed by polymer-incarcerated gold nanoclusters under ambient conditions. Green Chem. 2010, 12, 776-778. [CrossRef]

13. Suvith, V.; Philip, D. Catalytic degradation of methylene blue using biosynthesized gold and silver nanoparticles. Spectrochim. Acta A Mol. Biomol. Spectrosc. 2014, 118, 526-532. [CrossRef] [PubMed]

14. Murayama, T.; Haruta, M. Preparation of gold nanoparticles supported on $\mathrm{Nb}_{2} \mathrm{O}_{5}$ by deposition precipitation and deposition reduction methods and their catalytic activity for CO oxidation. Chin. J. Catal. 2016, 37, 1694-1701. [CrossRef]

15. Xiong, Z.; Qin, F.; Huang, P.S.; Nettleship, I.; Lee, J.K. Effect of Synthesis Techniques on Crystallization and Optical Properties of Ag-Cu Bimetallic Nanoparticles. JOM 2016, 68, 1163-1168. [CrossRef]

16. Tuteja, J.; Nishimura, S.; Ebitani, K. Change in reactivity of differently capped AuPd bimetallic nanoparticle catalysts for selective oxidation of aliphatic diols to hydroxycarboxylic acids in basic aqueous solution. Catal. Today 2016, 265, 231-239. [CrossRef]

17. Wu, W.; Lei, M.; Yang, S.; Zhou, L.; Liu, L.; Xiao, X.; Jiang, C.; Roy, V.A. A one-pot route to the synthesis of alloyed $\mathrm{Cu} / \mathrm{Ag}$ bimetallic nanoparticles with different mass ratios for catalytic reduction of 4-nitrophenol. J. Mater. Chem. A 2015, 3, 3450-3455. [CrossRef]

18. Xiang, J.; Li, P.; Chong, H.; Feng, L.; Fu, F.; Wang, Z.; Zhang, S.; Zhu, M. Bimetallic Pd-Ni core-shell nanoparticles as effective catalysts for the Suzuki reaction. Nano Res. 2014, 7, 1337-1343. [CrossRef]

19. Yan, J.M.; Wang, Z.L.; Gu, L.; Li, S.J.; Wang, H.L.; Zheng, W.T.; Jiang, Q. AuPd-MnOx/MOF-graphene: An efficient catalyst for hydrogen production from formic acid at room temperature. Adv. Energy Mater. 2015, 5, 4502-4505. [CrossRef]

20. Liu, Z.; Dong, W.; Cheng, S.; Guo, S.; Shang, N.; Gao, S.; Feng, C.; Wang, C.; Wang, Z. $\mathrm{Pd}_{9} \mathrm{Ag}_{1}-\mathrm{N}$-doped-MOF-C: An efficient catalyst for catalytic transfer hydrogenation of nitro-compounds. Catal. Commun. 2017, 95, 50-53. [CrossRef]

21. Puthiaraj, P.; Pitchumani, K. Palladium nanoparticles supported on triazine functionalised mesoporous covalent organic polymers as efficient catalysts for Mizoroki-Heck cross coupling reaction. Green Chem. 2014, 16, 4223-4233. [CrossRef]

22. Shang, L.; Bian, T.; Zhang, B.; Zhang, D.; Wu, L.Z.; Tung, C.H.; Yin, Y.; Zhang, T. Graphene-supported ultrafine metal nanoparticles encapsulated by mesoporous silica: Robust catalysts for oxidation and reduction reactions. Angew. Chem. 2014, 126, 254-258. [CrossRef]

23. Guo, D.; Shibuya, R.; Akiba, C.; Saji, S.; Kondo, T.; Nakamura, J. Active sites of nitrogen-doped carbon materials for oxygen reduction reaction clarified using model catalysts. Science 2016, 351, 361-365. [CrossRef] [PubMed]

24. Óvári, L.; Berkó, A.; Majzik, Z.; Kiss, J. Formation of Rh-Au core-shell nanoparticles on $\mathrm{TiO}_{2}(110)$ surface studied by STM and LEIS. Langmuir 2010, 2, 2167-2175. [CrossRef] [PubMed]

25. Óvári, L.; Bugyi, L.; Majzik, Z.; Berkó, A.; Kiss, J. Surface structure and composition of Au-Rh bimetallic nanoclusters on $\mathrm{TiO}_{2}(110)$ : A LEIS and STM study. J. Phys. Chem. C 2008, 112, 18011-18016. [CrossRef]

26. Massaro, M.; Colletti, C.G.; Lazzara, G.; Milioto, S.; Noto, R.; Riela, S. Halloysite nanotubes as support for metal-based catalysts. J. Mater. Chem. A 2017, 5, 13276-13293. [CrossRef]

27. Massaro, M.; Riela, S.; Cavallaro, G.; Colletti, C.G.; Milioto, S.; Noto, R.; Parisi, F.; Lazzara, G. Palladium supported on Halloysite-triazolium salts as catalyst for ligand free Suzuki cross-coupling in water under microwave irradiation. J. Mol. Catal. A Chem. 2015, 408, 12-19. [CrossRef]

28. Zhang, Y.; Tang, A.; Yang, H.; Ouyang, J. Applications and interfaces of halloysite nanocomposites. Appl. Clay. Sci. 2016, 119, 8-17. [CrossRef] 
29. Cavallaro, G.; Danilushkina, A.A.; Evtugyn, V.G.; Lazzara, G.; Milioto, S.; Parisi, F.; Rozhina, E.V.; Fakhrullin, R.F. Halloysite nanotubes: Controlled access and release by smart gates. Nanomaterials 2017, 7, 199. [CrossRef] [PubMed]

30. Cavallaro, G.; Lazzara, G.; Milioto, S.; Parisi, F. Hydrophobically modified halloysite nanotubes as reverse micelles for water-in-oil emulsion. Langmuir 2015, 31, 7472-7478. [CrossRef] [PubMed]

31. Fakhrullina, G.I.; Akhatova, F.S.; Lvov, Y.M.; Fakhrullin, R.F. Toxicity of halloysite clay nanotubes In Vivo: A Caenorhabditis elegans study. Environ. Sci. Nano 2015, 2, 54-59. [CrossRef]

32. Kryuchkova, M.; Danilushkina, A.; Lvov, Y.; Fakhrullin, R. Evaluation of toxicity of nanoclays and graphene oxide In Vivo: A Paramecium caudatum study. Environ. Sci. Nano 2016, 3, 442-452. [CrossRef]

33. Machado, G.S.; de Freitas Castro, K.A.D.; Wypych, F.; Nakagaki, S. Immobilization of metalloporphyrins into nanotubes of natural halloysite toward selective catalysts for oxidation reactions. J. Mol. Catal. Chem. 2008, 283, 99-107. [CrossRef]

34. Wang, R.; Jiang, G.; Ding, Y.; Wang, Y.; Sun, X.; Wang, X.; Chen, W. Photocatalytic activity of heterostructures based on $\mathrm{TiO}_{2}$ and halloysite nanotubes. ACS Appl. Mater. Interfaces 2011, 3, 4154-4158. [CrossRef] [PubMed]

35. Cavallaro, G.; Lazzara, G.; Massaro, M.; Milioto, S.; Noto, R.; Parisi, F.; Riela, S. Biocompatible poly(N-isopropylacrylamide)-halloysite nanotubes for thermoresponsive curcumin release. J. Phys. Chem. C 2015, 119, 8944-8951. [CrossRef]

36. Lvov, Y.M.; DeVilliers, M.M.; Fakhrullin, R.F. The application of halloysite tubule nanoclay in drug delivery. Expert Opin. Drug Deliv. 2016, 13, 977-986. [CrossRef] [PubMed]

37. Bonifacio, M.A.; Gentile, P.; Ferreira, A.M.; Cometa, S.; De Giglio, E. Insight into halloysite nanotubes-loaded gellan gum hydrogels for soft tissue engineering applications. Carbohydr. Polym. 2017, 163, 280-291. [CrossRef] [PubMed]

38. Fakhrullin, R.F.; Lvov, Y.M. Halloysite clay nanotubes for tissue engineering. Nanomedicine 2016, 11, 2243-2246. [CrossRef] [PubMed]

39. Li, J.; Liu, C.Y.; Liu, Y. Au/graphene hydrogel: Synthesis, characterization and its use for catalytic reduction of 4-nitrophenol. J. Mater. Chem. 2012, 22, 8426-8430. [CrossRef]

40. Rostami-Vartooni, A.; Nasrollahzadeh, M.; Alizadeh, M. Green synthesis of perlite supported silver nanoparticles using Hamamelis virginiana leaf extract and investigation of its catalytic activity for the reduction of 4-nitrophenol and Congo red. J. Alloys. Compd. 2016, 680, 309-314. [CrossRef]

41. Giribabu, K.; Suresh, R.; Manigandan, R.; Munusamy, S.; Kumar, S.P.; Muthamizh, S.; Narayanan, V. Nanomolar determination of 4-nitrophenol based on a poly (methylene blue)-modified glassy carbon electrode. Analyst 2013, 138, 5811-5818. [CrossRef] [PubMed]

42. Urkude, K.; Thakare, S.R.; Gawande, S. An energy efficient photocatalytic reduction of 4-nitrophenol. J. Environ. Chem. Eng. 2014, 2, 759-764. [CrossRef]

43. Silambarasan, S.; Vangnai, A.S. Biodegradation of 4-nitroaniline by plant-growth promoting Acinetobacter sp. AVLB2 and toxicological analysis of its biodegradation metabolites. J. Hazard. Mater. 2016, 302, 426-436. [CrossRef] [PubMed]

44. Ahmaruzzaman, M.; Gayatri, S.L. Batch adsorption of 4-nitrophenol by acid activated jute stick char: Equilibrium, kinetic and thermodynamic studies. Chem. Eng. J. 2010, 158, 173-180. [CrossRef]

45. Murugaesan, P.; Aravind, P.; Guruswamy, M.N.; Kandasamy, S. Performance of three different anodes in electrochemical degradation of 4-para-nitrophenol. Environ. Technol. 2015, 36, 2618-2627. [CrossRef] [PubMed]

46. Mandlimath, T.R.; Gopal, B. Catalytic activity of first row transition metal oxides in the conversion of p-nitrophenol to p-aminophenol. J. Mol. Catal. A Chem. 2011, 350, 9-15. [CrossRef]

47. Lara, L.R.; Zottis, A.D.; Elias, W.C.; Faggion, D.; de Campos, C.E.M.; Acuña, J.J.S.; Domingos, J.B. The catalytic evaluation of in situ grown Pd nanoparticles on the surface of $\mathrm{Fe}_{3} \mathrm{O}_{4} @$ dextran particles in the p-nitrophenol reduction reaction. RSC Adv. 2015, 5, 8289-8296. [CrossRef]

48. Wang, D.; Li, Y. One-pot protocol for Au-based hybrid magnetic nanostructures via a noble-metal-induced reduction process. J. Am. Chem. Soc. 2010, 132, 6280-6281. [CrossRef] [PubMed]

49. Xiong, Y.; McLellan, J.M.; Yin, Y.; Xia, Y. Synthesis of palladium icosahedra with twinned structure by blocking oxidative etching with citric acid or citrate ions. Angew. Chem. 2007, 119, 804-808. [CrossRef]

50. Jiang, H.L.; Akita, T.; Ishida, T.; Haruta, M.; Xu, Q. Synergistic catalysis of Au@Ag core-Shell nanoparticles stabilized on metal-Organic framework. J. Am. Chem. Soc. 2011, 133, 1304-1306. [CrossRef] [PubMed] 
51. Chen, X.; Cai, Z.; Chen, X.; Oyama, M. AuPd bimetallic nanoparticles decorated on graphene nanosheets: Their green synthesis, growth mechanism and high catalytic ability in 4-nitrophenol reduction. J. Mater. Chem. A 2014, 2, 5668-5674. [CrossRef]

52. Jiang, F.; Li, R.; Cai, J.; Xu, W.; Cao, A.; Chen, D.; Zhang, X.; Wang, C.; Shu, C. Ultrasmall Pd/Au bimetallic nanocrystals embedded in hydrogen-bonded supramolecular structures: Facile synthesis and catalytic activities in the reduction of 4-nitrophenol. J. Mater. Chem. A 2015, 3, 19433-19438. [CrossRef]

53. Zhu, H.Z.; Lu, Y.M.; Fan, F.J.; Yu, S.H. Selective hydrogenation of nitroaromatics by ceria nanorods. Nanoscale 2013, 5, 7219-7223. [CrossRef] [PubMed]

54. Liu, C.H.; Liu, R.H.; Sun, Q.J.; Chang, J.B.; Gao, X.; Liu, Y.; Lee, S.T.; Kang, Z.H.; Wang, S.D. Controlled synthesis and synergistic effects of graphene-supported PdAu bimetallic nanoparticles with tunable catalytic properties. Nanoscale 2015, 7, 6356-6362. [CrossRef] [PubMed]

55. Ai, L.; Yue, H.; Jiang, J. Environmentally friendly light-driven synthesis of Ag nanoparticles in situ grown on magnetically separable biohydrogels as highly active and recyclable catalysts for 4-nitrophenol reduction. J. Mater. Chem. 2012, 22, 23447-23453. [CrossRef]

56. Lv, J.J.; Wang, A.J.; Ma, X.; Xiang, R.Y.; Chen, J.R.; Feng, J.J. One-pot synthesis of porous Pt-Au nanodendrites supported on reduced graphene oxide nanosheets toward catalytic reduction of 4-nitrophenol. J. Mater. Chem. A. 2015, 3, 290-296. [CrossRef]

57. Huang, J.; Zhang, L.; Chen, B.; Ji, N.; Chen, F.; Zhang, Y.; Zhang, Z. Nanocomposites of size-controlled gold nanoparticles and graphene oxide: Formation and applications in SERS and catalysis. Nanoscale 2010, 2, 2733-2738. [CrossRef] [PubMed]

58. Veisi, H.; Gholami, J.; Ueda, H.; Mohammadi, P.; Noroozi, M. Magnetically palladium catalyst stabilized by diaminoglyoxime-functionalized magnetic $\mathrm{Fe}_{3} \mathrm{O}_{4}$ nanoparticles as active and reusable catalyst for Suzuki coupling reactions. J. Mol. Catal. A Chem. 2015, 396, 216-223. [CrossRef]

59. Zhu, Y.; Zhou, X.; Chen, D.; Li, F.; Xue, T.; Ahmed, S.F. Ternary $\mathrm{Fe}_{3} \mathrm{O}_{4} @ P A N I @ A u$ nanocomposites as a magnetic catalyst for degradation of organic dyes. Sci. China Tech. Sci. 2017, 60, 749-757. [CrossRef]

60. Xie, Y.; Qian, D.; Wu, D.; Ma, X. Magnetic halloysite nanotubes/iron oxide composites for the adsorption of dyes. Chem. Eng. J. 2011, 168, 959-963. [CrossRef]

(C) 2017 by the authors. Licensee MDPI, Basel, Switzerland. This article is an open access article distributed under the terms and conditions of the Creative Commons Attribution (CC BY) license (http:/ / creativecommons.org/licenses/by/4.0/). 